\title{
How Does FDI Affect Albania's Export Performance
}

\author{
Aurel Korocia, Erjona Deshatia
}

\begin{abstract}
Foreign Direct Investment (FDI) accounts for the largest and most important proportion of foreign capital in Albania, which undoubtedly plays an important role in the Albania's economic development growth. However, as the country continues to take various preferential policies to promote foreign investment and the good momentum of Albania's economic development, FDI increases. While there are considerable theoretical treatments of the FDI-export linkage, relevant empirical analyses have been limited. This paper attempts to close the gap by investigating the issue with the Albanian data. The estimates indicate that FDI indeed has had a positive impact on Albanian export performance. The findings provide rich source of information to policy makers, researchers, and the management of both foreign and domestic owned firms. From this point of view, the study aims to make an empirical research how the FDI has influenced the trade growth of the country. Based on the theory of FDI, this paper through an FDI and foreign trade model tests the correlation between two of them and effect of FDI in Albania's international trade with data from 1996-2014. The results of the study showed that there is a positive relation between FDI and exports in Albania.
\end{abstract}

\section{Keywords}

FDI, exports, international trade, Albania

Financial and industrial globalization is increasing substantially and is creating new opportunities for both industrialized and developing countries. The largest impact has been on developing countries because they now are able to attract foreign investors and foreign capital. At present, by seeing direct investment as main factor of speeding up economic globalization process, Foreign Direct Investment (FDI) has presented a number of notable features in Albania: (1) The operation of foreign investment factors increasingly focuses on the larger multinational companies; (2) Investment directions are mostly inclined to labor-intensive industries and service related industries; and (3) Increasing international direct investment has become the link of increase and development of international trade.
The keen interest of FDI within the trade community has been stimulated because they are interlinked in a variety of ways. For the issue that questions if FDI actually partly replaced or made possible creation of a large-scale international trade, the answer depends on the theoretical assumptions and practical tests. From this point of view, this paper analyzes the role of FDI in promoting foreign trade expansion in Albania. Albania has great potential to become a significant exporter of labor-intensive products, such as textiles and other consumer goods.

\footnotetext{
aAlbanian University of Tirana, Albania

Correspondent Author:

Aurel Koroci, Blv. Zogu I-rë, Tirana, Albania
} 
However, the Albanian firms faced immense difficulties at the initial stage in setting up a distribution network, keeping in close touch with rapid changes in consumer tastes, mastering the technicalities of industrial norms and safety standards, and building up a new product image. In many cases, the design, packaging, distribution, and servicing of the products are as important as the ability to produce them at, or below, ruling prices in world markets. The lack of such skills constituted a key barrier for Albania to enter the world markets.

\section{MATERIALS AND METHODS}

The objective of this study is to investigate how FDI affects exports quantity development in Albania. The authors test hypotheses using data collected from Bank of Albania. The data represent annual time series of 1996-2014 FDI utilization and total trade, imports, and exports. You can see data at table below (Table 1). The authors use that to verify if FDI promoted the export growth in Albania by positive analysis.

For analyzing FDI effect on promoting trade expansion, the proposed hypotheses are as following:

$\mathrm{H}_{1}$ : There is a positive correlation between FDI and export growth.

To get sustainable and statistically important results, the model below has been subject of some econometric tests.

\section{LITERATURE REVIEW}

\section{FDI Effects on Foreign Trade Expansion}

Relationship between International trade and transnational investment can be seen as early as Mundell (1957). Mundell put the substitutability of trade and capital flows in a different way: An increase in trade impediments stimulates factor movements, and an increase in impediments to factors stimulates trade. He pointed at the possible interaction between trade and capital flows. In the case of existence of international trade barriers, if an enterprise involves in international direct investment, on basis of relatively high efficiency or low switching costs based on factors of production, it can achieve the complete replacement of the merchandise trade. Vernon's (1966) research on product life cycle theory further developed an idea where he considered that FDI is the alternative to a higher level of foreign trade enterprise behavior. Kojima (1975) raised the marginal production expansion theory saying that in the external sector, according to some relative cost advantage, a country should develop a comparative advantage in the industry, correspondingly shall export that industry's products; in international direct investment, the capital flows from investing country and shall go to industries with marginal comparative disadvantage industries and because host country due to a lack of capital, technology, and management knowledge did not play all the potential comparative advantage in this industry before, so in this way between the two countries, it widens gap between the cost comparison and makes better conditions for larger international trade.

For the issue that questions if FDI actually partly replaced or made possible creation of a large-scale international trade, the answer depends on the theoretical assumptions and practical tests. According to UNCTAD (1999) on the empirical study on relation between FDI inflows and foreign trade performance based on the sample data for 52 developed and developing countries, empirical results show that, in general terms, FDI on international trade has been facilitated. South Korean scholars, Lim and Moon's (2001) research also confirmed that, when developed countries make investments to developing countries, if investment is newly established or investment industry is a sunset industry at home country, then between FDI and foreign trade, there is a certain positive correlation. Xian et al. (1999) and other scholars also believe that FDI in Albania has an important role in promoting export trade. Overall, the 
host country attracting FDI, to a certain extent, promoted the growth of its foreign trade.

\section{Host Country's Ability to Use FDI for International Trade Expansion}

The results show that the implementation of open policy and the development of a country's foreign trade is conducive to the promotion of economic development. We can check from the three components which make national economy demand, except that part of domestic demand (consumption and investment), there are some external demand (net exports). Net exports are regarded as part of country's gross domestic product, when it brings increase in the national disposable income, more funds can be used to expand production line; a country by using its export sector can improve other industries through input-output links effect, and pass the impact of export expansion to other industries; export trade expands the scope of the market, so domestic production can be consumed out of the domestic market and can overpass restrictions on market size. With increasing returns to scale industries, it can achieve economies of scale, at the same time, expansion of market promotes technological innovation; export trade also promotes development in country's resources and uses them without restrictions on the domestic market. Kojima (1975) first studied the relationship between FDI and host country foreign trade to make complementary relationship model, the model shows that: (1) FDI is not only the international flow of capital but also includes multinational companies' technology and management knowledge transfer. FDI brings not only the funds needed to host country's economic development, but also brings advanced technology and business management knowledge; (2) Based on FDI capital, technology and business management knowledge will pass from local branches of multinational corporations in host country's local firms, so it produces a positive "spillover effect", making the host country related industries and enterprises to have significant improvement in production technology and management experience which finally will create many new trade opportunities and promote the development of the host country's foreign trade.

Helpman, Melitz, and Yeaple (2003) showed that whether the relationship is complementary or subsidiary, it is an issue that depends on the type of FDI. The FDI could be of two different types: horizontal (MNEs have a subsidiary in every country of interest because of transport costs or just to be closer to the final customer) or vertical (MNEs locate each stage of the production process in different countries according to cost advantages). The models of "horizontal" FDI denote the predominantly negative impact on exports and establish, therefore, a relationship of substitution. Markusen and Venables (1996) developed such a model considering countries that are different in factor endowments and technologies and discovered that trade and FDI have a reverse (substitution) relationship as they become similar considering the relative factor endowments and technologies. Moreover, Markusen (1984) predicted a substitution relationship between horizontal FDI and exports, whereas horizontal FDI arises as a product of the interaction of plant-level activities and firm-specific activities (R\&D, marketing, managerial services, etc.). Therefore, whether an MNE establishes an affiliate or tends to export, it depends on the trade costs (tariffs) on the one hand, and the costs of establishing a new firm near the customers on the other hand. Finally, as horizontal FDI tends to take place between countries that are similar in terms of factor endowment, income, and technologies, the model predicts a negative link between skill differences and horizontal FDI. Other theoretical contributions, however, show that outward FDI and trade might be complements. The model of Helpman (1984) implies that in the case of vertical FDI, there are complementarities between the trade flows of final goods from foreign affiliates to parent 
firms and intra-firm transfers of intermediate goods from parent firms to foreign affiliates. In general, the model suggests that vertical FDI is likely to occur between developed and developing countries. For example, a firm's presence on a foreign market with one product may increase the total demand for the entire line of products (Lipsey and Weiss 1984). Another reason for complementarity could be that an investment by a manufacturer may increase the exports of inputs from the home market to the host market (Swensson 1997). Recent studies attempt to combine both horizontal and vertical motives for FDI (Carr, Markusen, and Maskus 2001). These models are referred to as knowledge-capital models and are based on three central assumptions. First, the location of knowledge-based assets could be spread geographically; second, knowledge-based assets yield higher skill intensity relative to production; and third, knowledge-based assets could be used in multiple plants. Accordingly, the models predict several combinations of vertical and horizontal multinationals and imply that horizontal FDI is more prevalent for countries with similar factor endowment and with high trade costs. In addition, vertical FDI arises when countries differ substantially in terms of factor endowments and when trade costs are low. Trade and FDI between developed countries, therefore, could be regarded as substitutes while FDI and trade between developed and developing countries are likely to be complements. Thus, the theoretical arguments do not provide, a priori and clear-cut relation between outward FDI and exports. Both substitution and complementary relationships are possible depending on various factors such as tariffs, type of goods, and type of FDI.

\section{DATA ANALYSIS}

Theoretically, there is a positive correlation between FDI utilization and the development of foreign trade: Because general multinational investment in the host country is always with a majority of processing elements, and then exports the finished products. According to the data from Bank of Albania, from 1996 to 2014, the total imports and exports in Albania have increased from 513 million to 5.6362 billion (euro), the total trade got nearly 11 times increase during 10 years.

\section{FDI Effects on Export Growth in Albania}

The analysis in first part of this section indicates that FDI and total trade have a very high correlation. In this part, the authors will continue to verify if FDI promoted the export growth in Albania by positive analysis.

The empirical equation is as follows:

Take the total exports in Albania as explained variable, and FDI as explanatory variable, get the regression model:

$$
L N\left(A L_{-} E X\right)=\alpha+\beta L N\left(A L_{-} F D I\right)+\varepsilon \quad(4.4)
$$

$\alpha$ and $\beta$ are the coefficients of constant and explanatory variables, $\varepsilon$ is the random error term.

Using the annual statistic data from CEIC, Bank of Albania, 1996-2014, the regression results are as follows:

$$
L N\left(A L_{-} E X\right)=1.03+0.94 L N\left(A L_{-} F D I\right)
$$

The $\mathrm{R}^{2}$ in the regression equation is .69 , adjusted $\mathrm{R}^{2}$ equals to .68 , the regression coefficient has already passed $\mathrm{T}$ test, the equation is well fitted in total. The variable coefficient suggests that if the FDI increases for $1 \%$, the exports will increase $0.94 \%$. The result shows that FDI has promoted the exports growth in Albania, and improved the export capacity of Albania.

\section{CONCLUSIONS}

Relationship between international trade and transnational investment can be seen as substitution model of trade and investment. Overall, the host country attracting FDI, to a certain extent, promoted the growth of its foreign trade. FDI has been viewed 
Table 1. Trade and FDI, Albania 1996-2014

\begin{tabular}{lllll}
\hline Year & $\begin{array}{l}\text { Exports total } \\
\text { (USD mn) }\end{array}$ & $\begin{array}{l}\text { Imports total } \\
\text { (USD mn) }\end{array}$ & $\begin{array}{l}\text { FDI } \\
\text { (USD mn) }\end{array}$ & $\begin{array}{l}\text { Foreign trade total } \\
\text { (USD mn) }\end{array}$ \\
\hline 1991 & 79.61 & 54.72 & 19.5 & 134.33 \\
1992 & 132.96 & 41.46 & 30.2 & 174.42 \\
1993 & 84.04 & 48.44 & 41.7 & 132.47 \\
1994 & 110.33 & 131.20 & 45.3 & 241.52 \\
1995 & 136.59 & 228.27 & 56.9 & 364.86 \\
1996 & 95.99 & 417.07 & 78.2 & 513.06 \\
1997 & 85.61 & 293.35 & 97.3 & 378.96 \\
1998 & 62.97 & 244.45 & 138 & 307.42 \\
1999 & 263.68 & $1,139.51$ & 185 & $1,403.19$ \\
2000 & 261.48 & $1,090.84$ & 152.5 & $1,352.32$ \\
2001 & 304.93 & $1,330.70$ & 207.3 & $1,635.63$ \\
2002 & 330.28 & $1,503.72$ & 135 & $1,834.00$ \\
2003 & 447.93 & $1,864.06$ & 178 & $2,311.99$ \\
2004 & 605.21 & $2,308.85$ & 341.8 & $2,914.06$ \\
2005 & 658.22 & $2,618.05$ & 264.5 & $3,276.27$ \\
2006 & 797.72 & $3,058.49$ & 306.7 & $3,856.21$ \\
2007 & $1,077.58$ & $4,187.51$ & 389.4 & $5,265.09$ \\
2008 & $1,354.83$ & $5,250.60$ & 343.9 & $6,605.43$ \\
2009 & $1,087.92$ & $4,548.28$ & 305.6 & $5,636.20$ \\
\hline
\end{tabular}

Note: Source: Bank of Albania.

as an accelerator of host countries' economic growth. One of its major potential growth-contribution is to promote host countries' exports. This study attempts to empirically investigate the issue by using the Albanian industrial data. The estimates indicate that FDI indeed has a positive impact on Albanian export boom, its effects are much larger than those of domestic capital, and its effects are larger in labor-intensive industries, as one might anticipate.

After analyzing the data collected from Bank of Albania, these findings are concluded:

There is a reinforcing relationship between FDI utilization and foreign trade of Albania. FDI and total trade have a very high correlation as it can be seen from the table.

FDI has promoted the exports growth in Albania and improved the export capacity of Albania.

In order to stimulate economic development, Albania should pay particular attention to improving the business environment by implementing regulatory reforms and adopting the new bankruptcy law.

Albania needs to diversify its economy and improve productivity by attracting foreign capital into tradable sectors among other things. Additional efforts should be made in order to achieve economic integration with EU.

\section{References}

Aitken, B. and A. Harrison. 1991. “Are There Spillovers From Foreign Direct Investment?-Evidence From Panel Data For Venezuela." Unpublished paper. MIT and the World Bank, November.

_ 1999. "Do Domestic Firms Benefit From Direct Foreign Investment? Evidence From Venezuela." American Economic Review 89(3):605-618.

Almeida, P. and B. Kogut. 1999. "Localization of Knowledge and the Mobility of Engineers in Regional Networks." Management Science 45(7):905-917.

Athukorala, P. and J. Menon. 1995. "Developing With Foreign 
Investment: Malaysia." The Australian Economic Review 28(1):9-22.

Blomstrom, M. and E. Wolff. 1994. "Multinational Corporations and Productivity Convergence in Mexico." In Convergence of Productivity: Cross-National Studies and Historical Evidence, edited by W. Baumol, R. Nelson, and E. Wolff. Oxford: Oxford University Press.

Blomstrom, M. and H. Persson. 1983. "Foreign Direct Investment and Spillover Efficiency in an Underdeveloped Economy: Evidence From the Mexican Manufacturing Industry." World Development 11(6):493-501.

Borensztein, E., J. D. Gregorio, and J. W. Lee. 1995. "How Does Foreign Direct Investment Affect Economic Growth?" NBER Working Paper No. 5057. National Bureau of Economic Research.

—. 1998. "How Does Foreign Direct Investment Affect Economic Growth?" Journal of International Economics 45(1):115-135.

Carr, D. L., J. R. Markusen, and K. E. Maskus. 2001. "Estimating the Knowledge Capital Model of the Multinational Enterprise." American Economic Review 91(3):693-708.

Caves, R. E. 1974. "Multinational Firms, Competition, and Productivity in Host-Country Markets." Economica 41(162):176-193.

Helpman, E. 1984. "A Simple Theory of International Trade With Multinational Corporations." Journal of Political Economy 92(3):451-471.

Helpman, E., M. Melitz, and S. R. Yeaple. 2003. "Export Versus FDI." NBER Working Paper No. 9439. National Bureau of Economic Research.

Holtz-Eakin, D., W. Newey, and H. Rosen. 1988. "Estimating Vector Autoregressions With Panel Data." Econometrica 56(6):1371-1395.

Kojima, K. 1975. "International Trade and Foreign Direct Investment: Substitutes or Complements." Hitotsubashi Journal of Economics 16:1-12.

Koroci, A. 2008. "Is the Albania's FDI Excessive?-Based on the Empirical Research of Crowding-out (Into) Effect." International Conference, Tirana, Albania, May 2008, first volume, p. 79.

Lim, S.-H. and H.-C. Moon. 2001. "Effects of Outward Foreign Direct Investment on Home Country Exports: The Case of Korean Firms." Multinational Business Review 9(1):42-49.

Lipsey, R. E. and N. Y. Weiss. 1984. "Foreign Production and Exports of Individual Firms." Review of Economics and Statistics 66: 304-307.
Markusen, J. R. 1984. "Multinationals, Multi-plant Economies, and the Gains From Trade." Journal of International Economics 16(3-4):205-226.

—. "Incorporating the Multinational Enterprise Into the Theory of International Trade." Journal of Economic Perspectives 9:169-189.

Markusen, J. R. and A. J. Venables. 1996. "The Increased Importance of Direct Investment in North Atlantic Economic Relationships: A Convergence Hypothesis." Pp. 169-188 in The New Transatlantic Economy, edited by M. B. Canzoneri, W. J. Ethier, and V. Grilli. Cambridge: Cambridge University Press.

Moon, H. C. and T. W. Roehl. 1993. "An Imbalance Theory of Foreign Direct Investment." Multinational Business Review 1(1):56-65.

—. 2001. "Unconventional Foreign Direct Investment and the Imbalance Theory." International Business Review 10:197-215.

Mundell, R. 1957. "International Trade and Factor Mobility." American Economic Review 47:321-335.

Swenson, D. L. 1997. "Explaining Domestic Content: Evidence From Japanese and US Automobile Production in the United States." In Effects of US Trade Protection and Protection Policies, edited by R. C. Feenstra. Chicago: University of Chicago Press.

UNCTAD. 1999. World Investment Report: Transnational Corporations and Export Competitiveness. New York: United Nations.

Vernon, R. 1966. "International Investment and International Trade in the Product Cycle." Quarterly Journal of Economics 80(2):190-207.

Xian, G. M., C. Zhang, Y. G. Zhang, S. Q. Ge, and J. X. Zhan. 1999. "The Interface Between Foreign Direct Investment and the Environment: The Case of China." UNCTAD, April 1999.

\section{Bios}

Aurel Koroci, Ph.D., lecturer, Faculty of Economy, Albanian University of Tirana, Albania; research fields: aspects of modern economic analysis and its applications and effects in economy.

Erjona Deshati, Ph.D., lecturer, Faculty of Economy, Albanian University of Tirana, Albania; research fields: marketing and management. 